\title{
Directive scrutiny of conglomerate stalk saltation
}

\author{
Rajiv Bhandari \\ Department of Mechanical Engineering SVITS Indore
}

\begin{abstract}
:
Reducing weight whereas increasing or maintaining strength of product is attending to be extremely vital scrutiny issue during this times. Conglomerate materials area unit one of the material families that area unit attracting researchers and being solutions of such issue. The auto business has shown increase interest for replacement of steel stalk Spring with that of conglomerate stalk Spring, since the stuff has high strength to weight quantitative relation, smart corrosion resistance properties. The report describes static scrutiny of steel stalk spring and conglomerate stalk spring. The objective is to compare the load carrying capability, stiffness and weight savings of conglomerate stalk Spring with that of steel stalk Spring. The dimensions of Associate in nursing existing typical steel stalk spring of a Light design calculations. Static Scrutiny of model of stalk Spring is performed victimization ANSYS eleven.0 The result of FEA is additionally through an experiment verified. The stress induced in the C-glass/Epoxy conglomerate stalk Spring is sixty fourth less than that of the steel Spring nearly and the deformation induced in the C-glass/Epoxy conglomerate stalk Spring is fifty seven less than that of the steel Spring nearly. This study leaves wide scope for future investigations. It will be extended to newer conglomerates victimization different reinforcing phases and the resulting experimental findings are often equally analyzed
\end{abstract}

Keywords: Conglomerate-glass/epoxy, steel, Experimental analysis.

\section{INTRODUCTION}

In order to examine natural resources and save cash energy, weight reduction has been the main focus of automobile manufacturer within the contemporary world. It's identified that the failure nature of steel stalk springs is sometimes common. It's vital to scale back accidents and to interchange steel stalk springs by bit by bit failing FRP (fiber bolstered polymer) stuff. Weight reduction is achieved primarily by the introduction of higher Material, style improvement and higher producing Processes. The suspension Spring is one among the potential things for weight reduction in automobile as it accounts for 10 to simple fraction of the unsprang weight. This 
helps in achieving the vehicle with improved riding qualities. It is well identified that springs are designed to absorb and store energy and so unharness it. Hence, the strain energy of the fabric becomes a serious think about coming up with the Springs. Comparedto steel Spring, the conglomerate Spring is found to possess sixty four.95\% higher stiffness and $126.98 \%$ higher natural frequency than that of existing steel stalk Springs. Multi stalk springs utilized in the automotive vehicles commonly carries with it full length leaves and graduated length leaves. What is more the conglomerate spring has lower stresses compared to steel spring. Conglomerate materials offers chance for substantial weight saving. Spring ar style to soak up \& store energy \& then unharness it thus strain energy of fabric becomes major factors in coming up with the spring. The spring permits the movement of wheel over obstacles \& then once returns the wheel to its traditional position

\section{Suspension System:}

The automobile chassis is mounted on the axles, not direct but some quite springs. This could be done to isolate the vehicle body from the road shocks, which may be at intervals the type of bounce, pitch and roll. These tendencies produce to associate uncomfortable ride and together cause additional stress at intervals the car frame body. All the [*fr1], that performs the perform of analytic the car from the road shocks, is together said as a system. It includes the Springing device used and diverse mountings for identical. Generally, suspension consists of a spring and a damper. The energy of road shock causes the spring to oscillate.

\section{Conglomerate Materials:}

Conglomerate materials square measure superior to all or any different renowned structure materials in specific strength and stiffness, warm temperature strength, fatigue strength and different properties. The desired combination of properties will be tailored in advance and accomplished in the manufacture of a specific material. Moreover, the material will be formed in this method as shut as doable to the type of final merchandise or maybe structural units. Conglomerate materials square measure advanced materials whose elements take issue powerfully from one another within the properties, square measure reciprocally insoluble or solely slightly soluble and divided by distinct boundaries.

\section{APPLICATIONS OF CONGLOMERATE MATERIALS:}

-Fiber epoxy conglomerates are employed in engine to boost the performance of the system. The pilot's cabin door of aircrafts has additionally been created with fiber glass rosin conglomerates and these area unit currently employed in different transport systems 


\section{The American Journal of \\ Engineering and Technology}

VOLUME01 ISSUE01

-In Railway automobileriages it's fascinating to cut back the load of rail car bodies further as significant transport vehicles that successively cut back power and braking necessities. It additionally reduces maintenance prices.

-Assembling of varied elements is sometimes done by adhesive bonding, mistreatment resins that area unit catalyzed to cure at temperature in a very short time.

-An vital thought within the use of conglomerates is light-weight weight.

\section{Design Selection:}

The spring behaves sort of a merely supported beam and also the flexural scrutiny is finished considering it as a merely supported beam. The merely supported beam is subjected to each bending stress and cross shear stress. Flexural rigidity is Associate in nursing necessary parameter within the spring style and check bent increase from 2 ends to the middle. Constant Thickness, varied dimension Design: during this style the thickness is unbroken constant over the entire length of the spring whereas the dimension varies from a minimum at the 2 ends to a most at the middle. Constant dimension, varied Thickness Design: during this style the dimension is unbroken constant over the complete length of the spring whereas the thickness varies from a minimum at the 2 ends to a most at the middle. Constant Cross-Selection Design: during this style each thickness and dimension area unit varied throughout the spring such the crosswise space remains constant along the length of the spring. Out of the higher than mentioned style ideas, the constant crosswise style technique is chosen because of the subsequent reasons:-

-Due to its capability for production and accommodation of continuous reinforcement of fibers.

-Since the crosswise space is constant throughout the spring, same amount of reinforcement fiber and organic compound will be fed unendingly throughout manufacture.

-Also this can be quite appropriate for filament winding method.

\section{Procedure for Testing:}

1. The Spring to be tested is examined for any defects like cracks, surface finishing, etc.

2. Move the plunger up to desired height in order that we are able to fix the fixture and spring for check.

3. Fix the position of fixture. On the fixture place the specimen. 


\section{The American Journal of \\ Engineering and Technology}

VOLUME01 ISSUE01

4. The load is applied at the center of spring, the vertical deflection of the spring center is recorded at desired interval.

\section{CONCLUSION}

The conclusion of the work is to minimize stress and deformation in C-Glass/Epoxy conglomerate stalk Spring compared to steel Spring for automobile suspension. Are often\} done to attain the following-It can be determined from the comparison that the bending stress induced within the C-Glass/Epoxy conglomerate Spring is sixty fourth less than the traditional steel Spring for a similar load carrying capability.

1. This style helps in the replacement of typical steel stalk Springs with conglomerate mono-stalk Spring with higher ride quality.

2. To bring home the bacon weight reduction within the suspension by exchange steel spring with mono conglomerate spring.

\section{REFERENCES}

[1]Errol Sancaktar, Mathieu Grattan "Design, Analysis, and improvement Of Conglomerate Stalk Springs For lightweight Vehicle Applications".

[2]H.A.Qureshi [2]"Automobile Spring from conglomerate material" Journal of fabric process technology.

[3]Mahmoud M. Shokrieh, Devoid Rezaei "Scrutiny and improvement of a conglomerate stalk spring" Conglomerate Structures sixty.

[4]M.A. Osipenko, R.N. Rudakov "A contact downside within the theory of spring bending" International Journal of Solids and Structures forty.

[5]Gluer Siddaramanna Shiva Ravi Shankar, Samba gam "Mono Conglomerate Spring For lightweight Weight Vehicle -Design, finish Joint Scrutiny and Testing" Materials Science.

[6]J.P. Hoi, J.Y. Cherruault, I. Nariño, R.M. Mayer "Evolution of the eye-end style of a conglomerate spring for serious shaft loads"

[7]B.Vijaya Hindu deity, Satyanarayana "Static and Dynamic Scrutiny on Conglomerate Spring In serious Vehicle" International Journal of Advanced Engineering scrutiny and Studies. 